\title{
Examining the sustainability and development challenge in agricultural-forest frontiers of the Amazon Basin through the eyes of locals
}

\author{
Irene Blanco-Gutiérrez $^{1,2}$, Rhys Manners ${ }^{3}$, Consuelo Varela-Ortega ${ }^{1,2}$, Ana M. Tarquis ${ }^{1,4}$, Lucieta G. Martorano ${ }^{5}$, \\ and Marisol Toledo ${ }^{6}$ \\ ${ }^{1}$ CEIGRAM, Universidad Politécnica de Madrid (UPM), C/Senda del Rey 13, 28040 Madrid, Spain \\ ${ }^{2}$ Department of Agricultural Economics, Statistics and Business Management, ETSIAAB, \\ Universidad Politécnica de Madrid (UPM), Av. Complutense s/n, 28040 Madrid, Spain \\ ${ }^{3}$ International Institute of Tropical Agriculture (IITA), KG 563, Kigali, Rwanda \\ ${ }^{4}$ Department of Applied Mathematics, ETSIAAB, Universidad Politécnica de Madrid (UPM), \\ Av. Complutense s/n, 28040 Madrid, Spain \\ ${ }^{5}$ Embrapa Amazônia Oriental/NAPT Médio Amazonas, Avenida NS UM A, 98, Bairro Diamantino, \\ CEP 68020-640, Santarém, Pará, Brazil \\ ${ }^{6}$ Museo de Historia Natural Noel Kempff Mercado - Universidad Autónoma Gabriel René Moreno (UAGRM), \\ Av. Irala 565, casilla 2489, Santa Cruz de la Sierra, Bolivia
}

Correspondence: Irene Blanco-Gutiérrez (irene.blanco@upm.es)

Received: 1 May 2019 - Discussion started: 23 May 2019

Revised: 11 January 2020 - Accepted: 16 February 2020 - Published: 24 March 2020

\begin{abstract}
The Amazon basin is the world's largest rainforest and the most biologically diverse place on Earth. Despite the critical importance of this region, Amazon forests continue inexorably to be degraded and deforested for various reasons, mainly a consequence of agricultural expansion. The development of novel policy strategies that provide balanced solutions, associating economic growth with environmental protection, is still challenging, largely because the perspective of those most affected - local stakeholders - is often ignored. Participatory fuzzy cognitive mapping (FCM) was implemented to examine stakeholder perceptions towards the sustainable development of two agricultural-forest frontier areas in the Bolivian and Brazilian Amazon. A series of development scenarios were explored and applied to stakeholder-derived FCM, with climate change also analysed. Stakeholders in both regions perceived landscapes of socio-economic impoverishment and environmental degradation driven by governmental and institutional deficiencies. Under such abject conditions, governance and wellintegrated social and technological strategies offered socioeconomic development, environmental conservation, and re-
\end{abstract}

silience to climatic changes. The results suggest there are benefits of a new type of thinking for development strategies in the Amazon basin and that continued application of traditional development policies reduces the resilience of the Amazon to climate change, whilst limiting socio-economic development and environmental conservation.

\section{Introduction}

The Amazon basin is the world's richest biological reservoir and a globally significant carbon sink (Foley et al., 2007; Guimberteau et al., 2017). Since the 1960s, deforestation and forest degradation have weakened the basin's natural function, causing a substantial loss of biodiversity, provision of ecosystem services, and changes in local and global weather patterns (Harris et al., 2012; Haddad et al., 2015; Zemp et al., 2017). Weak governments and political instability in Amazonian countries have reduced capacity to halt deforestation and related expansion of illegal activities (Celentano et al., 2012; Rodrigues-Filho et al., 2015). Recent increases in de- 
forestation and megafire clearances reinforce the continued threatened state of the basin (Global Forest Watch, 2019). Moreover, future scenarios depict a reduction in tree coverage and increased drought in Amazonia (e.g. Malhi et al., 2008; Tejada et al., 2016; Guimberteau et al., 2017), with Lenton (2011) proposing that ecological tipping points could be reached.

Agricultural and extraction activities are cited as major drivers of deforestation and forest degradation in the Amazon basin (Hosonuma et al., 2012; García et al., 2019). These activities have, in many cases, been supported by policies to encourage rural development whose lasting benefits are unclear (Rodrigues et al., 2009; Celentano et al., 2012; Oliviera et al., 2013; Weinhold et al., 2015). Policies concentrating upon agricultural intensification and resource extraction may provide economic gains (Le Tourneau et al., 2013; Ioris, 2016), but they may also have negative long-term social and environmental impacts (Weinhold et al., 2015). Conversely, conservation policies aimed at preserving and restoring forest ecosystems have been implicated as drivers of negative socio-economic changes (Chomitz, 2007; Carr, 2009; Guedes et al., 2014). These findings point toward the tradeoffs in rural development objectives (McNeil et al., 2012), which increasingly focus on socio-economic development through extraction activities, or environmental conservation that excludes them. This dichotomy has dominated the political and developmental discourse of the Amazon for decades, with Nobre et al. (2016) suggesting it represent the basin's established development model.

The state and outlook of the Amazon basin, along with the limitations of the entrenched development policies, beg the question as to whether other options exist to transition the basin towards a sustainable, less conflict-ridden state. Nobre et al. (2016) promote a "third way", driven by investment in technical and social capital, catalysing a localised industrial revolution. The benefits derived from a technology-led transformational change have been highlighted by Guedes et al. (2014), who reveal that increased access to technical assistance may permit communities to develop more sustainable livelihoods, converting natural capital to social capital. Also, Lapola et al. (2014) infer that technological improvements along with sustainable land management could drive sustainable land use shifts. Other studies emphasise the importance of investing in social capital. Weinhold et al. (2015) and Caviglia-Harris et al. (2016) suggest that socio-economic development in forest frontier regions of Brazil has uncoupled from environmental exploitation and degradation, due to policy development and implementation. Tritsch and Arvor (2016) propose that recent improved governance structures have begun to address competing rural development goals. Godfray et al. (2011) and Newton et al. (2013) advocate that governance and institutional improvements could provide a balance between conservation, development, and climate change mitigation. The implementation of such reforms or similar strategies could offer an interesting discus- sion point to reassess the emphasis of rural development policies. However, consideration of novel strategies would be reliant upon modelling and testing, offering scope for scenario development and application. The development of such scenarios could aid in quantifying the impacts of potential strategies on improving factors within the three main rural development dimensions, social, economic, and environmental, whilst simultaneously mitigating climate change.

Engaging stakeholders in scenario development offers a wide range of potential benefits. It is argued that participatory scenario development can provide new interpretations of previously studied problems, improve the understanding of complex situations, reduce unforeseen consequences of policy implementation, and empower local communities (Folhes et al., 2015; Olazabal and Pascual, 2016). A number of methods are available to incorporate stakeholder perspectives into such analyses (e.g. Verburg et al., 2014), including fuzzy cognitive mapping (FCM). FCM involves the development of a visual representation (map) of perceptions of a given system (Kok, 2009) and permits the application of scenarios to these maps (Vasslides and Jensen, 2016).

In analysing the Amazon basin, most scenario discussions have been limited to the study of current and future deforestation trends ignoring the perspective of those most likely to be affected: local stakeholders (Folhes et al., 2015). Using stakeholder-derived information collected from workshops performed in forest frontier communities of the Bolivian and Brazilian Amazon (the province of Guarayos in Bolivia and the Tapajós National Forest in Brazil), this paper aims to identify how such communities perceive the state of their region using FCM. In general, deforestation and the expansion of the agricultural frontier in Bolivia have been less well studied than in Brazil, probably due to Bolivia's relatively recent development (Pacheco, 2006; Killeen et al., 2008). However, increasing efforts are being made to study both parts of the Amazon basin. Further, this analysis will apply development scenarios (including climate change) to these FCMs, analysing how each region reacts to the sustainability and development challenge and changing socioeconomic, political, and climatic conditions.

\section{Description of the study area}

Given the size of the Amazon basin, two study sites with similar problems were selected within the framework of the ROBIN $^{1}$ project. Firstly, the province of Guarayos $\left(20029 \mathrm{~km}^{2}\right)$, in the northwest corner of the department

\footnotetext{
${ }^{1}$ The research project ROBIN (The Role of Biodiversity in Climate change Mitigation) (2011-2015), funded by the European Union Seventh Framework Programme under grant agreement no. 283093, aims at quantifying interactions between terrestrial biodiversity, land use, and climate change potential in tropical Latin America. More information can be found at https://cordis.europa. eu/project/rcn/100815/reporting/ (last access: 1 May 2019).
} 


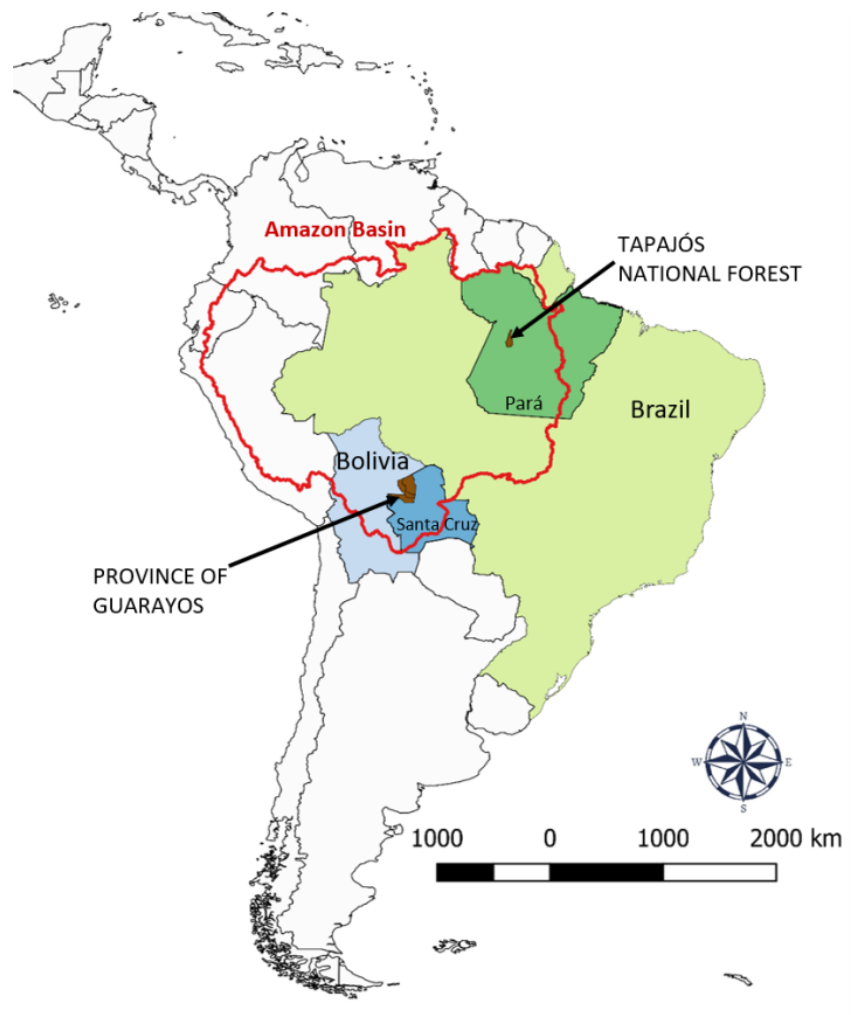

Figure 1. Location of the case study sites (the province of Guarayos in Bolivia and the Tapajós National Forest in Brazil). Case studies are shaded in brown. The department of Santa Cruz (Bolivia) is shaded in dark blue and the state of Pará (Brazil) is in dark green. The extent of the Amazon basin is outlined in red.

of Santa Cruz in lowland Bolivia, was selected. Secondly, the Tapajós National Forest $\left(5449 \mathrm{~km}^{2}\right)$ in the western part of the state of Pará (municipalities of Belterra, Placas, Rurópolis, and Aveiro) in northern Brazil, was selected (Fig. 1).

The province of Guarayos (henceforth Guarayos) is located in the transition zone between the humid Amazon forest and the dry Chiquitano forest. It has a tropical climate and hosts important protected forest areas, such as the "Reserva Nacional de Vida Silvestre Ríos Blanco y Negro" (dating from 1990). In the vicinity of these protected areas lives the Guarayos indigenous community (a branch of the Guaraní), whose livelihoods depend on fishing, hunting, and gathering fruit, as well as the cultivation of rice, pineapples, bananas, manioc, and other crops. The extraction of wood is limited, with only informal timber networks in place (Albornoz et al., 2008). Since 1996, land has been collectively owned and managed by the Guarayos through a "community land of origin", which has contributed to the sustainable conservation and utilisation of forests. However, legal uncertainty surrounding the system of land tenure in Bolivia coupled with increasingly frequent arrivals of large-scale farm operators in the area have resulted in highly conflicted situations, with illegal appropriation of common lands and en- vironmental degradation (Killeen et al., 2008; Stavenhagen, 2009). Agriculture is the main employer for the Guarayos and is the major source of income for households in this region of elevated poverty. Soya dominates both winter and summer cultivation, followed by sunflowers, maize, rice, and sorghum (INE, 2015).

The Tapajós National Forest (henceforth Tapajós) is located at the heart of the Amazonian rainforest in Brazil. The climate is humid tropical, and the natural vegetation is dense terra firme (upland) tropical moist forest (Dubois, 1976). Tapajós has been protected since 1974 (decree no. 73.684, 19 February 1974) and is classed as an IUCN (International Union for Conservation of Nature) category VI protected area (IBAMA, 2004). Most of the population live along the Tapajós River, in well-organised communities of ribeirinhos (or Caboclos, which derived from the intermingling between the first European colonialists and the Amerindian populations). These communities have historically been very active in governance processes. During a 30-year period (1980 2010), they led an important resistance movement to avoid eviction and gain land tenure and resource rights. This movement was pioneering in Brazil and led to a commercial community forest management system that has attracted both national and international attention (Bicalho and Hoefle, 2015). Despite this, the ribeirinhos face difficult living conditions, with poor access to social services. Logging is the main economic source for the population, who subsist on very low incomes subsidised by small-scale farming activities (manioc, beans, and corn), fishing, hunting, and non-logging activities (ecotourism and the sale of wood-latex-leather handicrafts). Most residents are dependent on government transfer payments (Hoefle, 2016). The environment and the protected areas inhabited by the ribeirinhos are increasingly threatened by the expansion of intensive agriculture and cattle grazing areas coming mainly from the neighbouring Cerrado and the development of infrastructure (highways and dams) for the acceleration of growth (Fearnside, 2007, 2015; Verburg et al., 2014; Gibbs et al., 2015).

\section{Methodology}

\subsection{Participatory development of FCMs}

The FCM concept is attributed to Kosko (1986), who provided the fuzziness to earlier cognitive mapping techniques (Tolman, 1948; Axelrod, 1976). Maps developed from FCM visualise components and their causal relationships within a system (Kok, 2009) as perceived by an individual, or group. This mapping can be developed through participatory interviews or workshops, where components (called nodes, concepts, or vertices) representing features of the system are identified, and causal relationships (links, connections, or arcs) between them are defined through weighted and meaningful directed linkages (Gray et al., 2015). The weight 


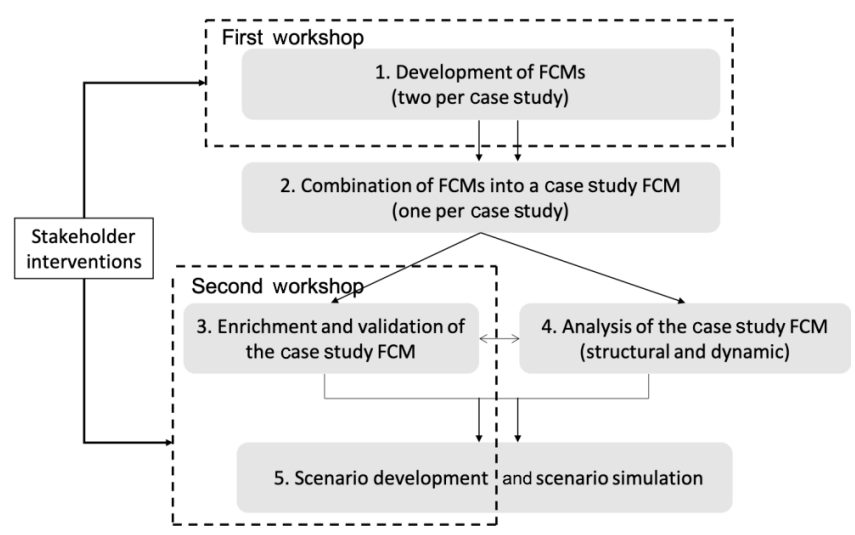

Figure 2. Methodological steps in the research.

of these relationships ranges from -1 to +1 (Özesmi and Özesmi, 2004) and defines the scale of influence (positive or negative) that one component has upon another.

The causal networks developed from FCM have considerable flexibility for analysis in a range of fields (e.g. Papageorgiou et al., 2013) and support scenario development (e.g. Kok, 2009). The methodology can incorporate multiple stakeholders' perspectives and knowledge through combination of multiple maps into one "community" map (Fairweather, 2010) or development of a single map by a group of stakeholders, incorporating distinct perspectives of different groups into a single vision (Varela-Ortega et al., 2013). Participatory development of FCMs can improve communication through the development of an open, neutral, and informal forum for participants to give their opinions. FCM can provide useful output for data-scarce problems or in areas where data are difficult to obtain and can be complementary to quantitative models (Olazabal and Pascual, 2016). In this study, we use FCMs to visualise the perceptions of local stakeholders concerning the direct or indirect interactions of variables that influence the state of the local environments in both Guarayos and Tapajós. The steps implemented as part of the methodology are illustrated in Fig. 2.

In each of the case studies, two stakeholder workshops were held within the framework of the ROBIN project. In the first, and following the author's previous experience from a large EU project (SCENES) (Kok and van Vliet, 2011), we facilitated two focus groups of 12 to 15 persons each to ease the process of producing FCM. As much as possible, the two focus groups were equally balanced in terms of gender, age, and stakeholder group representation. Each stakeholder group included representatives from the policy and private sectors, non-governmental organisations, and scientists, thus covering a broad range of expertise on agroforestry issues (Table 1).

Each focus group developed its own FCM. Thus, the FCM developed represented stakeholder group knowledge (Ösezmi and Ösezmi, 2004). Participants were invited to of- fer their perspectives on the present state of the environment in the region and what they considered to be the key features and processes inherent to it. First, every participant was asked to write up to three factors that they considered to contribute most to the present situation and explained their choices with the rest of the group. Following discussion, similar factors were clustered and new factors were identified and added to the original selection. After a final selection of factors was chosen, participants established links (arrows) among them and identified the sign of the links: positive $(+)$ when an increase in one factor causes an increase in the other and negative (-) when an increase in one factor causes a decrease in the other. Finally, they assigned values to these links indicating how strong they were using a scale within the range 0 (very weak) to \pm 1 (very strong).

After the first stakeholder workshop and following Ösezmi and Ösezmi (2004), the two group maps from each case study were combined into one "case study FCM". As part of the combination process, components identified as representing similar features were merged, where possible. However, in combining components, conflicting connections were identified, normally involving the wording "lack of". In these cases, and following Vasslides and Jensen (2016), wording of the more prevalent component was kept, and connection weights were inverted appropriately.

The combined FCM was presented in the second workshop for enrichment, validation, and interpretation. Once the case study FCM was agreed upon, a discussion on possible futures and sustainable strategies was held, serving as input for scenario development and simulation. To ensure continuity, care was taken that similar stakeholders (or stakeholder groups) were present in the second workshop.

\subsection{FCM analysis}

The two case study FCMs were analysed following Reckien (2014) and Olazabal and Pascual (2016) considering their structure and dynamics and the impacts of scenarios on their dynamics.

\subsubsection{Structural metrics}

As FCMs are considered complex networks, the structural metrics here used to analyse them are complex network parameters commonly applied in the literature (see Table S1 in the Supplement). Further, we also include two novel metrics for the measurement of centrality in FCM analysis: PageRank (PR) and betweenness (Bw). Centrality is used to determine the importance or influence of a given node in the network. This concept was first introduced in sociology to quantify the influence of an individual in the whole social network (Freeman, 1978). In the two networks analysed (FCM of Guarayos and Tapajós) the ties among nodes have weights assigned to them; therefore the FCMs are considered 
Table 1. Stakeholder workshops held in Guarayos (Bolivia) and Tapajós (Brazil).

\begin{tabular}{|c|c|c|c|c|}
\hline Case study & Workshops & $\begin{array}{r}\text { No. of } \\
\text { stakeholders }\end{array}$ & Stakeholder group & Name of stakeholder \\
\hline \multirow[t]{4}{*}{$\begin{array}{l}\text { Guarayos } \\
\text { (Bolivia) }\end{array}$} & \multirow[t]{2}{*}{$\begin{array}{l}\text { First: } \\
\text { 30 January } \\
2013\end{array}$} & \multirow[t]{2}{*}{30} & $\begin{array}{l}\text { Policy/ } \\
\text { administration }\end{array}$ & $\begin{array}{l}\text { Autonomous government of Santa Cruz (GDASC) } \\
\text { Forest and Land Audit and Social Control Authority (ABT) } \\
\text { Forestry services } \\
\text { Department of Natural Resources (DIRENA) } \\
\text { Department of Agriculture (SEDACRUZ) }\end{array}$ \\
\hline & & & Private sector & $\begin{array}{l}\text { Indigenous Guarayos Forestry Association (IRARAI) } \\
\text { Farmers federation } \\
\text { Guarayos Timber Association (AMAGUA) } \\
\text { Guarayos Cattle Association (AGUAGUA) }\end{array}$ \\
\hline & \multirow[t]{2}{*}{$\begin{array}{l}\text { Second: } \\
\text { 18 June } 2014\end{array}$} & \multirow[t]{2}{*}{27} & $\begin{array}{l}\text { Non-governmental } \\
\text { organisation }\end{array}$ & $\begin{array}{l}\text { Organization of Native Guarayos Peoples (COPNAG) } \\
\text { Guarayos Indigenous Women Centre (CEMIG) } \\
\text { Ascensión Inter-Ethnicity Centre (CIEA) } \\
\text { Rio Blanco and Rio Negro Wildlife Reserve }\end{array}$ \\
\hline & & & Research & $\begin{array}{l}\text { Tropical and Agricultural Research Centre (CIAT) } \\
\text { Instituto Boliviano de Investigación Forestal }\end{array}$ \\
\hline \multirow[t]{4}{*}{$\begin{array}{l}\text { Tapajós } \\
\text { (Brazil) }\end{array}$} & \multirow[t]{2}{*}{$\begin{array}{l}\text { First: } \\
27 \text { November } \\
2013\end{array}$} & \multirow[t]{2}{*}{23} & $\begin{array}{l}\text { Policy/ } \\
\text { administration }\end{array}$ & $\begin{array}{l}\text { Ministry of Agriculture (MAPA) } \\
\text { Federal government agency - Chico Mendes Institute for } \\
\text { Biodiversity Conservation (ICMBIO) } \\
\text { Institute of Technical Assistance and Rural Extension } \\
\text { (EMATER) }\end{array}$ \\
\hline & & & Private sector & Soybean production company \\
\hline & \multirow[t]{2}{*}{$\begin{array}{l}\text { Second: } \\
28 \text { November } \\
2013\end{array}$} & \multirow[t]{2}{*}{26} & $\begin{array}{l}\text { Non-governmental } \\
\text { organisation }\end{array}$ & $\begin{array}{l}\text { Indigenous communities (Flona Tapajós-Communidade do } \\
\text { Maguari) } \\
\text { Hope Foundation (IESPES) } \\
\text { The Nature Conservancy (TNC) }\end{array}$ \\
\hline & & & Research & $\begin{array}{l}\text { The Federal University of Western Pará (UFOPA) } \\
\text { EMBRAPA Eastern Amazon } \\
\text { Luiz de Quieroz College of Agriculture (ESALQ-USP) }\end{array}$ \\
\hline
\end{tabular}

weighted networks and the centrality measures are weighted as well.

Bw was first introduced by Freeman (1977) to quantify the control that an individual can achieve on the communication between other humans in a social network. PR was named after Larry Page (Page et al., 1999) and is used by Google to rank websites in their search results. While Bw measures the influence of a node within a network by calculating the number of times a node acts as an intermediary along the shortest path between two other nodes, PR calculates the probability of visiting each node if we were randomly "surfing" the net.

\subsubsection{Dynamic analysis}

Besides the structural metrics of Table S1, the dynamic behaviour of the maps was also analysed to gain an insight into how components interact with each other, over multiple iterations (Gray et al., 2015). This analysis permitted comparison between the steady-state values (Kosko, 1994) for each component and the simulation of scenarios

To calculate the steady-state values and perform the dynamic analysis, each case study FCM was converted into an adjacency matrix (Tables S2 and S3), which was then multiplied by a state vector $A$ (Eq. 1) over various iterations $(k)$. According to Kok (2009), this calculation results in four potential dynamic outcomes: components return to zero, components continuously increase or decrease, components continuously cycle, and components stabilise at a fixed value.

$A_{i}^{(k+1)}=f\left(A_{i}^{(k)}+\sum_{\substack{j \neq i \\ j=1}}^{N} A_{j}^{(k)} w_{j i}\right)$,

where $A_{i}^{(k+1)}$ is the value of the component $C_{i}$ at iteration $k+1, A_{i}^{(k)}$ is the value of component $C_{i}$ at iteration $k, A_{j}^{(k)}$ is the value of the component $C_{j}$ at iteration $k$, and $w_{i j}$ is the weight of the connection between components $C_{i}$ and $C_{j}$. 
The state vector $A$ initially sets values for all components to 1 (Olazabal and Pascual, 2016), assuming all components are equally important, and is multiplied against the adjacency matrix. The resultant vector is transformed to a logistic expression $f$, binding values between 0 and 1 (Kosko, 1986). This output vector is once again multiplied against the adjacency matrix, producing bound results between 0 and 1 . This process is repeated until the dynamic outcome becomes evident, usually after 20-30 iterations (Kok, 2009).

Output (steady-state) values close to 0 are representative of a strong decrease in the component, whereas values closer to 1 represent a strong increase (Reckien, 2014). The steadystate values were interpreted as the current state of each component within the system (map) and were used as a baseline for interpreting the impacts of the scenarios.

\subsection{Scenario development}

Development of scenarios can provide a useful mechanism to evaluate the localised impacts of potential policy implementation. In the present study, scenarios that mimic traditional rural development policies are compared with novel policy strategies, to analyse the system impacts on Guarayos and Tapajós. We designed and implemented four scenarios (Table 2). Two were implemented to replicate the binary development strategies traditionally applied in the region: agricultural development (Scenario 3) and environmental conservation (Scenario 4). A further two scenarios were developed: techno-social reforms (Scenario 1) to replicate the third way of Nobre et al. (2016) for rural development and governance reforms (Scenario 2) cited by stakeholders to be fundamental for sustainable futures in the region (Varela-Ortega et al., 2013). We also analysed the cumulative effects of climate change on each of the scenarios.

Following Reckien (2014) and based on discussions with stakeholders, we translated each scenario into the analysis through the manipulation of individual component state vector values ( $A$ of Eq. 1: Sect. 2.3.2) (Table 2). For each scenario, different components were identified as being directly affected by the scenario implementation. For these selected components, their values were fixed between 0 and 1 , depending upon the scale of the scenario's impact. A strong increase in the selected component was translated by a state vector value of 1 , whilst a strong decrease was set to 0 . Intermediate values represent less intense increases or decreases. All other components had their values set to 0 .

The output values for components under each scenario were then compared to their baseline values, with differences suggesting the relative impacts of each scenario. Further, the effects of the four development scenarios were also tested under the conditions of climate change, where the climate change component was fixed to 1 .

To determine the wider impacts of the scenarios on the system, cumulative impacts for each scenario were analysed. To do so, components were categorised as positive, negative,

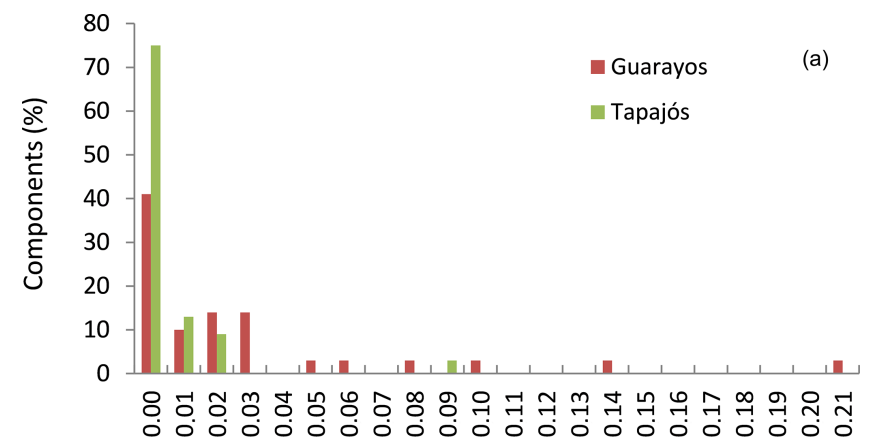

Betweenness

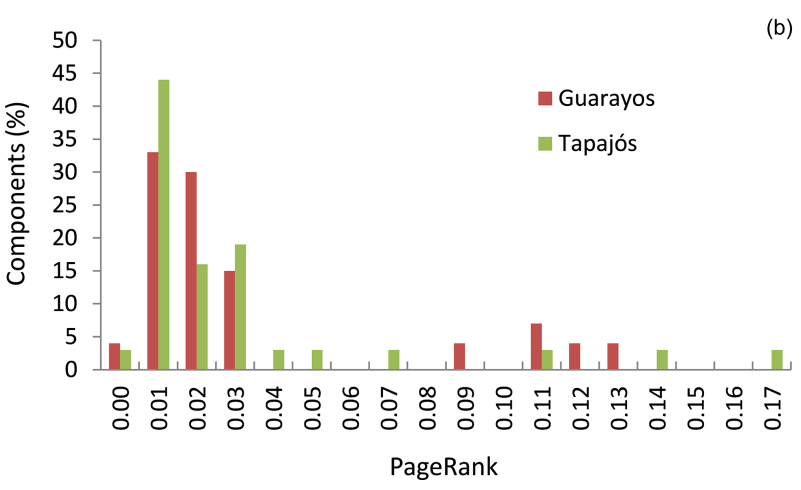

Figure 3. Frequencies of betweenness (a) and PageRank values (b) in both case studies: Guarayos (red) and Tapajós (green).

or neutral (Reckien, 2014; Olazabal and Pascual, 2016) (Table S4). Categorisation of components was based upon the perception of the role that each component would have in developing more sustainable regions. Components were categorised to recognise the equal importance of a reduction in a negative component as an increase in a positive one, when considering the cumulative impacts of the scenarios. As with Reckien (2014), an aggregated impact value was calculated as the sum of increases in positive components and decreases in negative components (from baseline to scenario).

It should be noted that the output results of FCMs are semi-quantitative. As such, outcomes can only be used to determine impacts on components, relative to other components, rather than absolute changes (Özesmi and Özesmi, 2004; Kok, 2009). Impact comparisons can only be made within the system and cannot be compared with absolute indicator values (Reckien, 2014; Devisscher et al., 2016).

\section{Results}

\subsection{Structure analysis of FCM}

Analysis of the two Case-Study FCMs demonstrated structurally similar systems (Table 3), with divergent contents (Figs. 3, 4, and 5). 


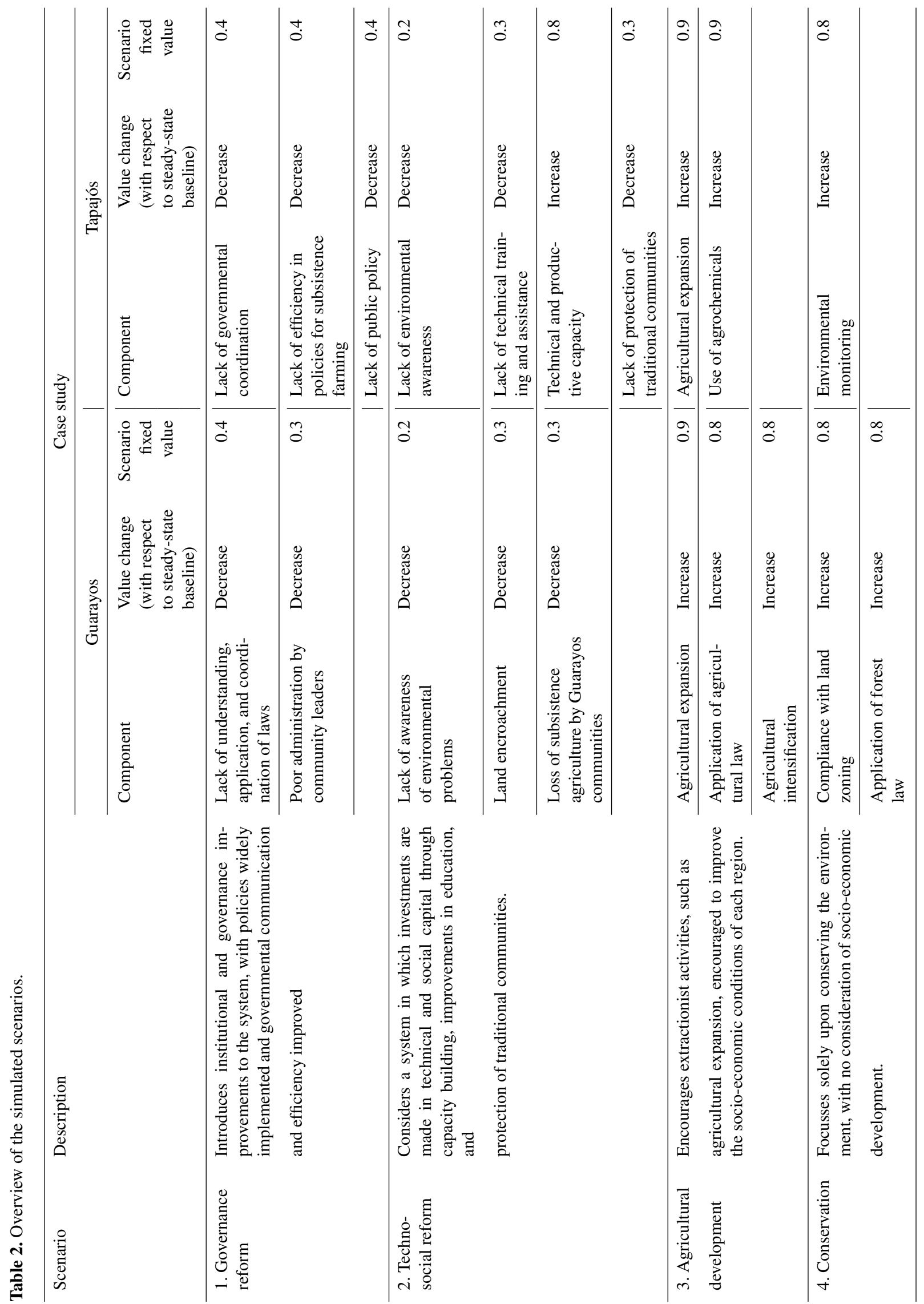




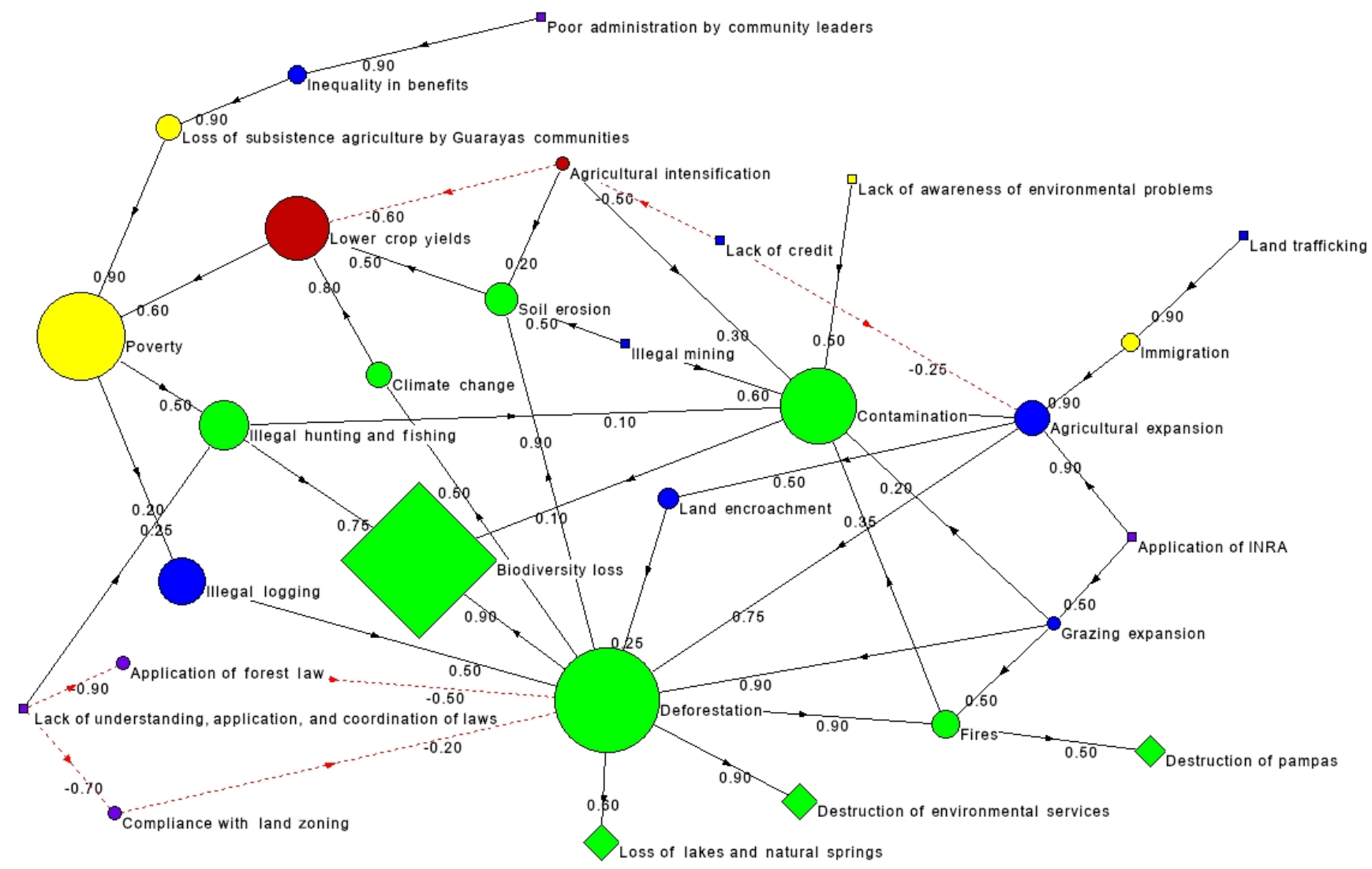

Figure 4. Network visualisation of the case study FCM developed by stakeholders in Guarayos. The size of each component represents their PageRank. Solid black lines represent positive connection weights and red dotted lines negative connection weights. The shape of each component represents its type (square: transmitter; circle: ordinary; diamond: receiver), and colours represent their grouping (green: environmental; blue: economic; yellow: social; purple: political/institutional; red: technical).

Table 3. Guarayos and Tapajós fuzzy cognitive map indices. Standard deviations shown in brackets and maximum values of the centrality indices.

\begin{tabular}{lrr}
\hline Indices & Guarayos & Tapajós \\
\hline Components & 29 & 32 \\
Transmitters & 7 & 9 \\
Receivers & 4 & 3 \\
Ordinary & 18 & 20 \\
Connections & 44 & 50 \\
Average connection weight (SD) & $0.57(0.26)$ & $0.61(0.22)$ \\
Connections per component & 1.52 & 1.56 \\
Density & 0.052 & 0.048 \\
Complexity & 0.57 & 0.33 \\
Betweenness & 0.21 & 0.09 \\
PageRank & 0.13 & 0.17 \\
\hline
\end{tabular}

The two maps have comparable component numbers and similar densities of 0.052 (Guarayos) and 0.048 (Tapajós). The Tapajós map has a greater number of causal relationships per component (1.56) than the Guarayos map (1.52), which explains its lower density value and a higher readiness to elicit change. The complexity of the Guarayos map (0.57) is almost double that of Tapajós (0.33), due to its lower number of transmitting components and higher number of receivers (Table 3). As a consequence, the Tapajós map shows a more hierarchical system, dominated by political and institutional concepts (Fig. 5), whilst the Guarayos map (Fig. 4) appears more heterogeneous.

A first look at the results obtained in Bw and PR (Table 3) shows that the maximum $\mathrm{Bw}$ value in Guarayos is double that in Tapajós, 0.21 and 0.09 respectively, as we observed with complexity. In both cases the highest Bw corresponds to deforestation. Meanwhile PR maximum values are more similar in both case studies but are higher in Tapajós than in Guarayos. Studying the value distribution for both metrics (BW and PR) in percentage of components, it is possible to 


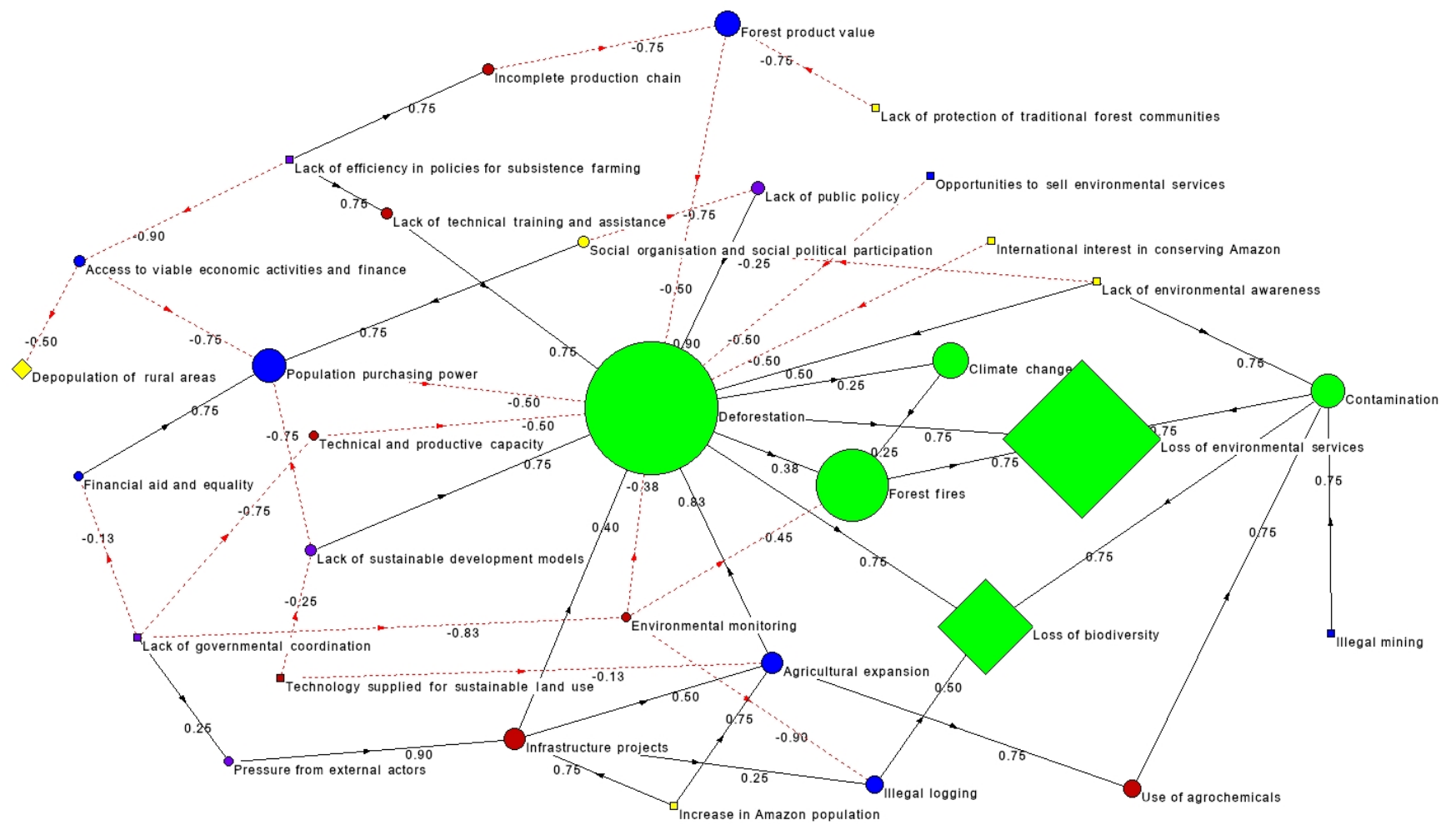

Figure 5. Network visualisation of the case study FCM developed by stakeholders in Tapajós. Size of each component represents their PageRank. Solid black lines represent positive connection weights and red dotted lines negative. Shape of each component represents its type (square: transmitter; circle: ordinary; diamond: receiver) and colours their grouping (green: environmental; blue: economic; yellow: social; purple: political/institutional; red: technical).

compare both cases. With respect to Bw (Fig. 3a), the highest six values are quite differentiated from the rest, ranging from 0.05 to 0.21 in Guarayos. These correspond with ordinary components: agricultural expansion, climate change, illegal logging, lower crop yields, and deforestation. In the case of Tapajós, there is only one differentiated value corresponding to deforestation. With respect to PR (Fig. 3b), both cases present several differentiated values that are visualised in the network (Figs. 3 and 4) for a deeper analysis.

Stakeholders perceived both systems as dominated by environmental problems, with deforestation and biodiversity loss having the highest PageRank value in Guarayos and Tapajós. It is also important to note the importance of poverty and low crop yields in Guarayos and forest product value and population purchasing power in Tapajós. For stakeholder in Guarayos, deforestation is the most influential component (highest outdegree; see Table S5) driving climate change, soil erosion, and biodiversity loss (Fig. 4), whereas in Tapajós deforestation was perceived as the most influenced component (highest indegree; see Table S6) affected by, amongst others, infrastructure projects, lack of public policy, and agricultural expansion (Fig. 5). In Tapajós, stakeholders depicted a lack of efficiency in policies for subsistence farmers as the factor with the greatest influence (highest outdegree; see Ta- ble S6), causing incomplete production chains, lack of technical capacity, and lack of access to viable economic activities (Fig. 5). Components including contamination and biodiversity loss were found in both maps to have high indegrees (see Tables S5 and S6), suggesting their sensitivity to other components.

In Guarayos and Tapajós the aggregated PageRank of the component groups was dominated by the environmental and economic groups, followed by political, social, and technical groups. In both maps, the environmental grouping is the most heavily influenced and sensitive group with the highest group indegree values. The components identified as transmitters (square components) were largely political and economic, mostly defined as ineffective or with negative connotations, with the use of words such as "lack of" or "poor". The influence of these components on the situation in both regions (Figs. 4 and 5) is supported by their outdegree values (Tables S5 and S6). The sensitivity of environmental components was once again demonstrated by the majority of receiver components (diamonds) being environmental.

Despite the differences in components within each map, there was still overlap between them, with 15 of the 61 total components representing similar concepts (environmental degradation, worsening socio-economic situations, and 


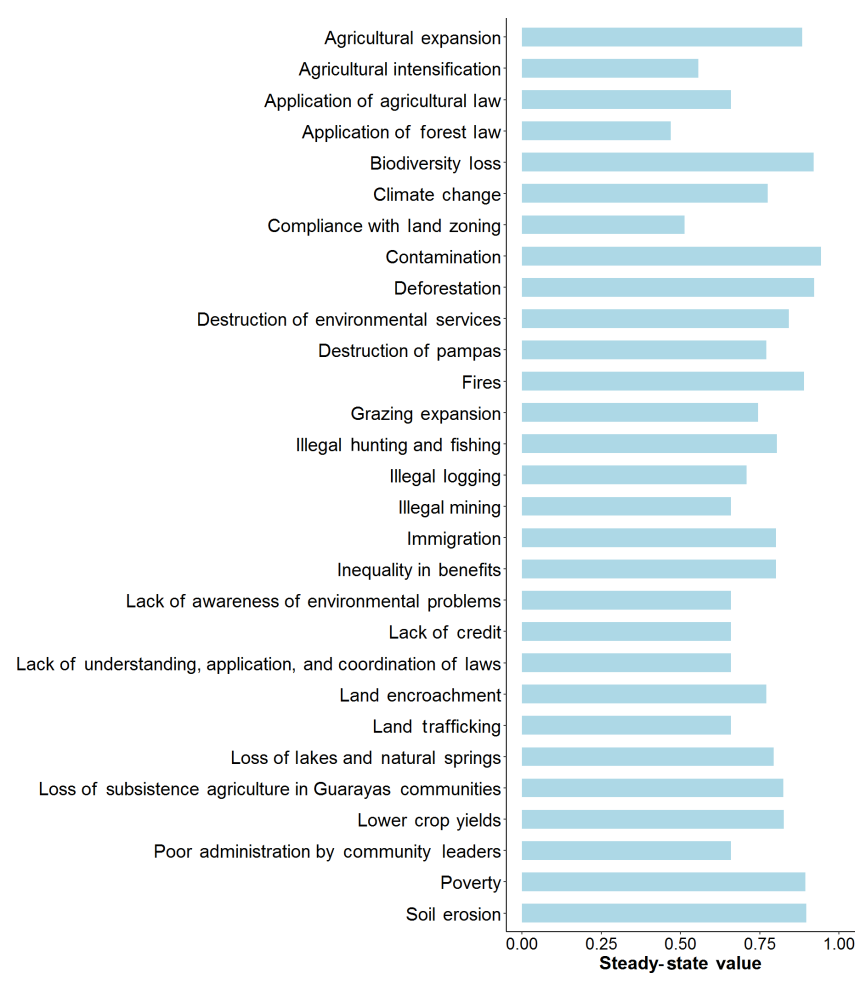

Figure 6. Component values for the Guarayos case study FCM under steady-state "baseline" conditions. Values close to 0 represent a strong decrease in the component, whilst values closer to 1 represent a strong increase.

poor governance). This suggests that despite the maps being developed in distinct regions and with unique stakeholders, there is some continuity in the problems that afflict both regions and potentially the basin as a whole.

\subsection{Dynamic analysis of FCM}

\subsubsection{Baseline situation}

Dynamic analysis of the aggregated maps (Figs. 6 and 7) demonstrates significant overlap, despite the $\sim 2000 \mathrm{~km}$ that separate the case studies. Both regions (Guarayos and Tapajós) are characterised by worsening environmental degradation and apparently bleak socio-economic opportunities for local communities, coupled with low institutional safeguards.

Figure 6 characterises Guarayos as a region where environmental degradation is high, facilitated by low (and declining) application of the forest law and poor (and worsening) compliance with land zoning, coupled with low socioeconomic opportunities. The system is dominated by increasing contamination, deforestation, loss of biodiversity, soil erosion, fires, poverty, and agricultural expansion.

The situation in Tapajós (Fig. 7) depicts a similarly degraded system, where environmental conditions are deteriorating, facilitated by limited economic opportunities and poor

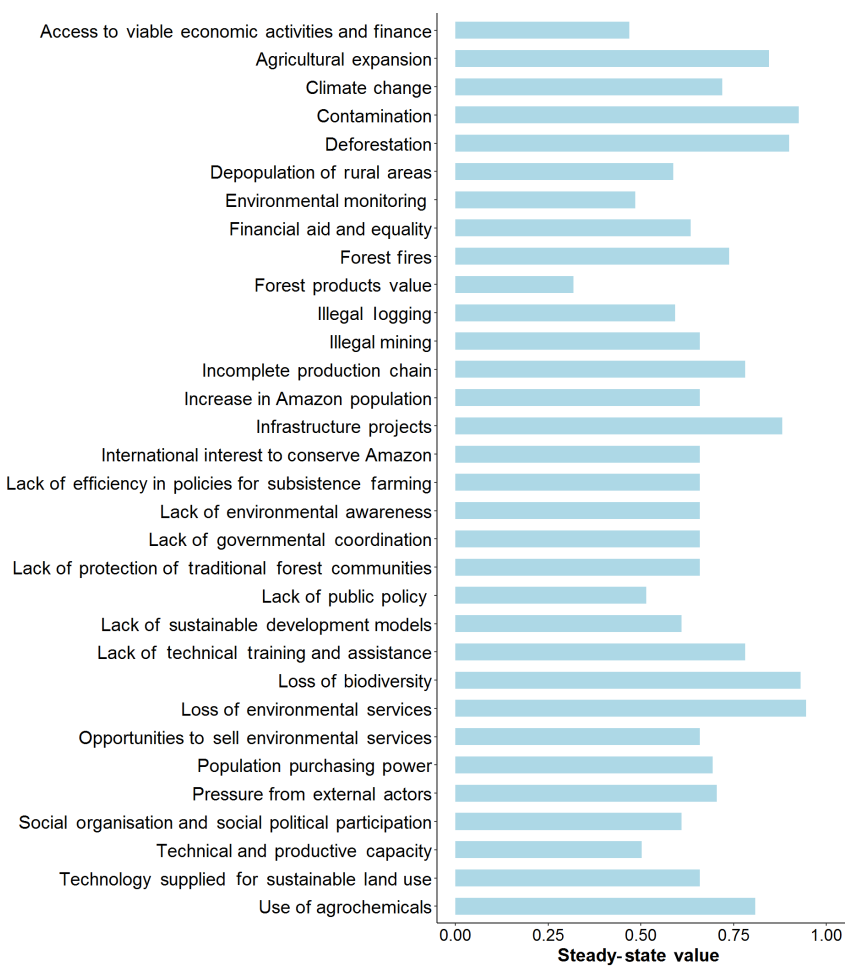

Figure 7. Component values for the Tapajós case study FCM under steady-state "baseline" conditions. Values close to 0 represent a strong decrease in the component, whilst values closer to 1 represent a strong increase.

environmental monitoring. Tapajós is dominated by loss of environmental services and biodiversity and increasing contamination, deforestation, infrastructure projects, and agricultural expansion. Along with this, socio-economic opportunities for locals are apparently diminishing with reducing value of forest products and limited access to viable economic activities. Further, monitoring of environmental degradation is inhibited by limited environmental monitoring.

\subsubsection{Scenario outcomes}

Figure 8 establishes the aggregate effects of the four development strategies on the mapped system. The values for the components fixed within each scenario have not been included, to highlight the subsequent systemic impacts of changes to components fixed within each strategy.

The governance strategy was responsible for the greatest "desired" change in both Guarayos and Tapajós, with the agricultural development strategy causing the biggest "undesired" change. The techno-social and conservation strategies also resulted in desirable changes.

A more detailed description of the individual impacts of the scenarios on components in both systems is given below, with the extent of component changes shown in Figs. S1 and S2. In general, implementation of these strategies results in 


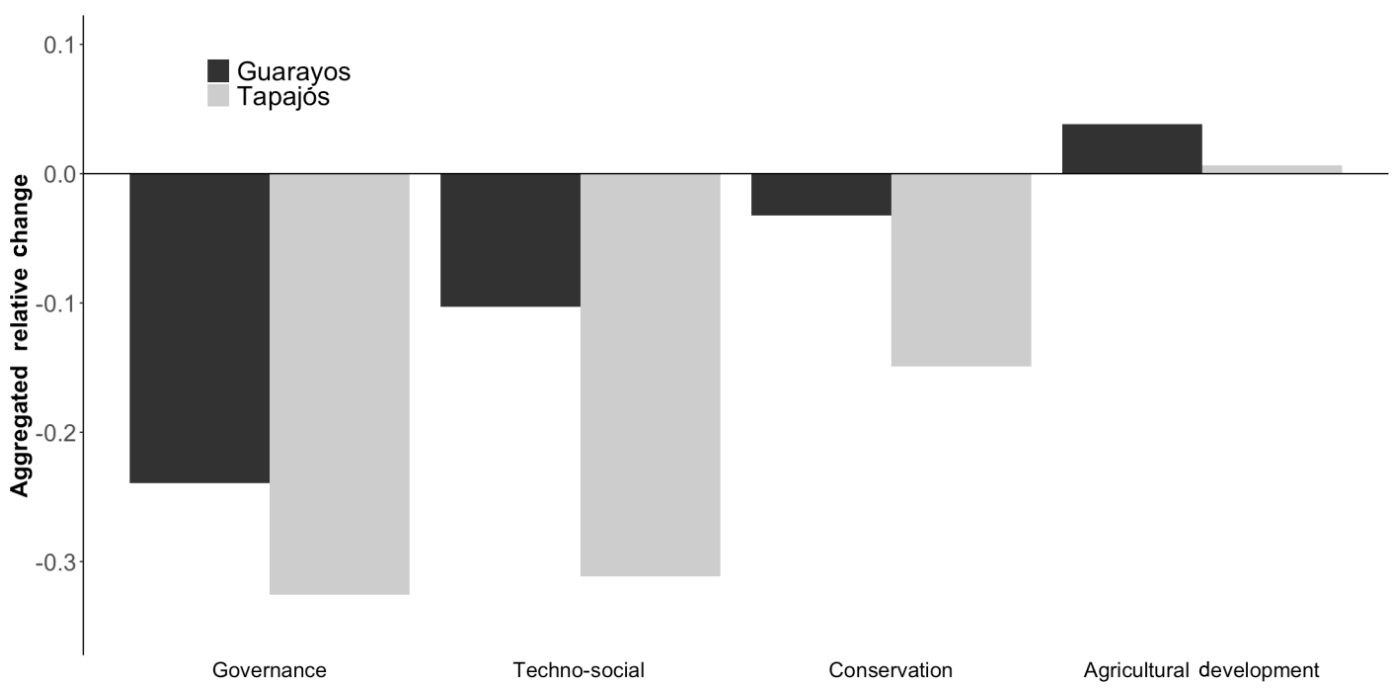

Figure 8. Aggregated relative change and response of scenarios, compared with baseline. Negative values represent a desirable change in the system. Positive values represent an undesirable change in the system.

greater changes to individual components in Guarayos than in Tapajós, which may be attributable to the higher density of the Guarayos map.

The governance strategy results in the greatest systemic relative changes and some of the greatest changes to individual components. This may demonstrate the integrated nature of governance components and their connectivity within both systems. The strategy encourages reductions in environmental degradation across the two systems including deforestation, logging, and forest fires. It also drives socio-economic improvements, reducing poverty, increasing access to financial aid and viable economic alternatives, improving population purchasing power in Tapajós, and reducing the inequality of benefits in Guarayos. In Tapajós, it also elicits considerable improvements in the technical capacity of the region.

The techno-social strategy encourages a suite of positive changes to both systems, reducing environmentally degrading activities, whilst providing simultaneous economic development. In Guarayos poverty is reduced, along with reductions in contamination, deforestation, illegal hunting, and logging. The strategy provides similar reductions in environmental degradation in Tapajós, with large reductions in deforestation and fires, whilst increasing population purchasing power and improving the value of forest products. Further, it also encourages greater social organisation and political participation, demonstrating a potentially beneficial unforeseen knock-on effect of such reforms.

The conservation strategy has limited impacts across the two systems, catalysing change only in environmental components. In Guarayos it reduces deforestation, whilst in Tapajós it reduces deforestation as well as other environmental degrading activities including forest fires, logging, deforestation, and biodiversity loss.
The agricultural development strategy encourages substantial differences in the responses of the two systems. In Guarayos, crop yields improve with the expansion in both agriculture and grazing expansion and result in reductions in poverty. Further, it also encourages positive environmental change with reduced illegal logging, hunting, and fishing. However, in general environmental conditions worsen greatly with, for example, increasing deforestation, along with contamination, soil erosion, loss of biodiversity, and destruction of pampas. In Tapajós, the rural development strategy results in no socio-economic benefits but encourages considerable environmental degradation, with deforestation, forest fires, loss of environmental services, and biodiversity and contamination all increasing.

Figure 9 demonstrates the sensitivity of the systems under each scenario, whilst experiencing continued climate change, with some scenarios demonstrating greater resilience than others.

Figure 9 reveals that the governance reforms (and to a lesser extent techno-social reforms) may provide the most effective and resilient means of instigating regional improvements, even under climate change. Guarayos is more heavily influenced by climate change than Tapajós, which, considering the PageRank of climate change in both systems (Figs. 4 and 5), may have been expected. In Guarayos, the effect of climate change was so great that despite the conservation strategy the overall state worsened, compared with the baseline. In Tapajós, the impacts of climate change were still notable but not to such an extreme extent as to further worsen the situation of the region. In both Guarayos and Tapajós, the agricultural development strategy offered the least resilient development strategy. 


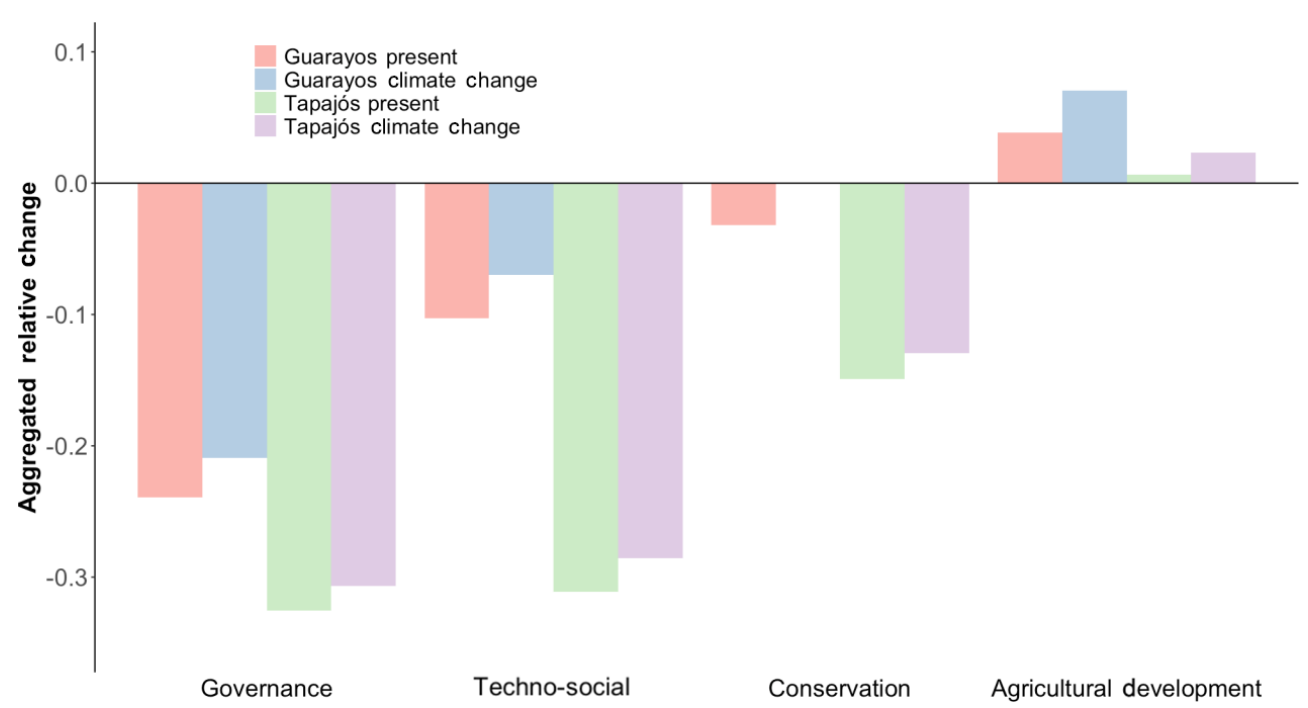

Figure 9. Aggregated relative change and response of scenarios under present climatic conditions and climate change. Negative values represent a desirable change in the system. Positive values represent an undesirable change in the system.

\section{Discussion}

\subsection{The current picture of the Amazon}

FCM afforded the combination of knowledge from regional experts and local community members, offering the opportunity to improve and enrich the understanding of these regions, whilst providing a low-resolution demonstration of their present state.

Despite the two maps reflecting systems on opposite sides of the Amazon, they yielded strikingly similar results on the present state of the basin. Stakeholders in both Bolivia and Brazil mapped systems plagued by environmental degradation, with weak social and governance support structures, inhibiting local community benefits. The perceived lack of effective governance is apparently incongruent with the contemporary literature, which suggests recent improvements in the governance model (World Bank, 2016). The presence of inequality, poverty, and deforestation is consistent with the paradox of poverty in resource-rich systems (Ioris, 2016), with stakeholders appearing to characterise the same "...landscapes of impoverishment..." as Ioris (2016, p. 187). Stakeholders in both Bolivia and Brazil identified similar barriers to development, with poor governance and conflicting policy measures inhibiting widespread socio-economic development and hindering environmental conservation, supporting previous findings (Simmons et al., 2007). Further, the inconsequential nature of climate change for stakeholders in both cases was unexpected, considering its already noted impacts (and potential future impacts; e.g. Malhi et al., 2008; Spracklen and Garcia-Carreras, 2015). This unanticipated outcome may support the findings of Brondizio and Moran (2008), who suggest that the memory of climatic changes is short-lived. This finding may also reflect the distinct cultural and linguistic meaning or representations of climate changes (e.g drought, flooding) across the two sites. In particular in Tapajós, climate change impacts are associated with an increase in extreme weather events (heatwaves, droughts) and soil dryness, which are considered a main cause of the wildfire occurrence in the region. Varela-Ortega et al. (2013) found that stakeholders perceived climate change to be a fundamental component in the future of both regions and in Tapajós at present.

\subsection{Encouraging positive change in the Amazon}

Implementation of the suite of scenarios affected substantial and variable changes. Governance and institutional reforms appear to offer the most effective means of transitioning Amazonian regions towards more sustainable desirable states, even under the conditions of climate change. The positive effects of governance and institutional reforms are unsurprising considering the constraining effect (McNeil et al., 2012) that poor governance can have by inhibiting sustainable development, with its effects well documented in the Amazon (e.g. Rodrigues-Filho et al., 2015). The results evidence the liberating effect that improving institutional capacity can have by instigating desirable social, economic, and environmental change. These multidimensional benefits apparently confirm the transversal nature of institutions and governance in the context of sustainable development (McNeil et al., 2012). The positive impacts of governance have precedence in the Amazon, where institutional and governance improvements have encouraged environmental conservation (Nepstad et al., 2014; Tritsch and Arvor, 2016) and socio-economic development (Caviglia-Harris et al., 2016). Further, the literature widely supports the need for strong governance and institutions, with Müller et al. (2014), Ver- 
burg et al. (2014), and Høiby and Zenteno-Hopp (2014) contending that the likelihood for long-term environmental conservation is slim under poor governance conditions. Lapola et al. (2014) promote the need for policy enforcement and institutional support to encourage sustainable development, whilst Guedes et al. (2014) propose that pathways towards future environmental conservation can be founded upon investments in local institutions.

Techno-social reforms also represent an alternative strategy, driving environmental protection, economic development, and social improvements. In Brazil, the difference in desired change between this strategy and governance reforms was minimal, suggesting its considerable potential. These results support the vision of Nobre et al. (2016), where rural development is encouraged through social and technological reforms, with both environmental and social components improving. The implementation of this scenario suggests that investments in building technical capacity and social reforms may reverse the poverty traps (Reardon and Vosti, 1995) in which stakeholders in both mapped regions appear to be locked. Investments in social and technical reforms may have wider unforeseen benefits, improving societal attitudes towards natural capital conservation (Salahodjaev, 2016), aiding in flattening environmental Kuznets curves (Tritsch and Arvor, 2016), and driving positive changes in agricultural methods (Assunção et al., 2013). Many of these points are suggested in the results of this analysis. However, this strategy was admittedly found to be susceptible to climate change, more so than the institutional reforms.

Traditional developmental strategies relying upon conservation or extractionist policy implementation have driven trade-offs across the Amazon (Le Tourneau et al., 2013). The impacts of these binary choices can be stark, with decision makers having to make substantial compromises between environmental conservation and agricultural development (e.g. Manners and Varela-Ortega, 2018). The application of the conservation strategy had limited system-wide impacts, resulting in environmental improvements but offering little opportunity for socio-economic development, potentially confining local communities to conditions of poverty and limited development. Further, implementation of such a narrow strategy was found to be particularly susceptible to climate change. The application of this strategy, or one similar, may have little chance of providing sustainable rural development without concomitant offering of economic alternatives for locals, or the need for systems like Payments for Ecosystem Services to potentially alleviate poverty and encourage conservation (Pinho et al., 2014). Tejada et al. (2016) found that limiting future environmental degradation, specifically deforestation, in the Bolivian lowlands without offering new economic alternatives is unlikely.

The results also outline the negative effects of a strategy solely focussing upon agricultural development, with the long-term benefits limited, especially under climate change. This strategy improved social factors like poverty and in- equality (in Bolivia), but at a cost to local ecosystems in both Bolivia and Brazil. The outcomes of this scenario appear consistent with the literature, suggesting that purely agriculturally orientated strategies without supporting policies may result in limited economic benefits for locals (Rodrigues et al., 2009; Ioris, 2016) and some environmental costs (Weinhold et al., 2015). Further, these results appear not to demonstrate the uncoupling of agricultural development from environmental degradation as identified in Brazil (CavigliaHarris et al., 2016). However, focussing solely upon the local-scale economic and social benefits of such extractive strategies, as touched upon by Celentano et al. (2012), may ignore their wider national developmental benefits.

In summary, application of the two traditional scenarios for rural development (agricultural development and environmental conservation) demonstrate the trade-offs in their application and their ability to improve regional economic, social, and environmental conditions. Development of new strategies concentrating upon governance and techno-social reforms could instigate positive shifts in the trajectory of these regions, even under the effects of climate change. However, moving from the modelled world to the real world, where implementation of such strategies requires consideration of social acceptability, likelihood of implementation, willingness of politicians and institutions to reform, coherence with current policy landscapes, and funding availability, may result in complications. Despite improvements in governance across many Amazonian countries in recent decades (World Bank, 2016), implementation of the governance reform may be challenging, especially under increasingly turbulent political landscapes, exemplified by Brazil. Further, potentially intangible (in the short term) and time-consuming governance and institutional reforms may be unpalatable for voter-conscious and electioneering administrations. Governments wanting to appear proactive in terms of rural development may consider other more palpable options. The benefits of institutional reforms may only be reaped in the long term, by which time governments may have changed and the benefits of change would be lost for the implementing administration. This may highlight the space for market-based interventions to encourage more sustainable development (e.g Nepstad et al., 2014; Gibbs et al., 2015). Beyond this, strategies aimed at techno-social reforms may garner fewer positive systemic changes but offer more tangible actions for voters and governments alike, whilst catalysing positive change, even under worsening climatic conditions. However, the financial implications of such reforms must be considered, with them likely requiring significant and long-term public or private investments (Ferraro and Pattanayak, 2006). Our results show that some techno-social measures, such as improving environmental awareness, may be effective to promote sustainability, while they do not necessarily require a large amount of public financial investment. Actions of social responsibility can contribute to financing investments in education and new technologies. Also, governance measures 
(e.g. better coordination of laws and institutions) can facilitate the adoption of more ambitious techno-social measures (e.g. better training and assistance, protection of traditional communities) at lower cost. Thus, further analysis should be performed on synergies between governance and technosocial measures, as well as on collective work between the public and the private sectors to better organise and prioritise investments and actions.

\section{Conclusions}

The use of FCM to visualise the perceptions of stakeholders across the Amazon basin has shown that on both sides of the basin landscapes of socio-economic impoverishment and environmental degradation are present, driven to varying degrees by governmental and institutional deficiencies. Even under such abject conditions, these processes have been modelled to be theoretically reversible through application of governance and well-integrated technical and social reform strategies. These strategies were found to encourage positive regional changes even under the pressure of climatic change. However, what is apparent in both regions is that a continuation of the current rural development programmes cannot continue, with these results showing that concentration on only conservation or agricultural development policies would reduce the resilience of both regions to climate change, whilst also providing limited socio-economic development and continued environmental degradation.

Data availability. Data are freely available upon request by contacting the corresponding author by email.

Supplement. The supplement related to this article is available online at: https://doi.org/10.5194/nhess-20-797-2020-supplement.

Author contributions. The conceptualisation and methodology design were performed by CVO (PI of Spain's research team in the ROBIN project) and IBG. The development and implementation of the stakeholder workshops were carried out by IBG, CVO, LGM, and MT. AT carried out the mathematical analysis of FCM. RM performed the simulations and supported the scenario development and processing of results. IBG and RM prepared the manuscript with contributions from all co-authors.

Competing interests. The authors declare that they have no conflict of interest.

Special issue statement. This article is part of the special issue "Remote sensing, modelling-based hazard and risk assessment, and management of agro-forested ecosystems". It is not associated with a conference.
Acknowledgements. The authors are indebted to the numerous stakeholders that have taken part in this research and to Paloma Esteve for their valuable comments throughout the development of the research.

Financial support. This research has been supported by the European Union's Seventh Framework Programme (project "Role Of Biodiversity In climate change MitigatioN (ROBIN)" (grant no. 283093)), the Universidad Politécnica de Madrid through their Latin American Cooperation Programmes (project "Biodiversidad y bienestar humano ante el cambio global en áreas tropicales protegidas de América Latina" (grant no. AL13-PID-18)), and the Universidad Politécnica de Madrid through their Latin American Cooperation Programmes (project "Biodiversidad y cambio climático en la Amazonía: Perspectivas socio-económicas y ambientales" (grant no. AL14-PID-12)).

Review statement. This paper was edited by Wenwu Zhao and reviewed by Pei-Lin Yu and two anonymous referees.

\section{References}

Albornoz, M., Cronkleton, P., and Toro, M.: Estudio regional Guarayos: Historia de la configuración de un territorio en conflicto, CEDLA and CIFOR, Santa Cruz, Bolivia, 2008.

Assunção, J., Bragança, A., and Hemsely, P.: High productivity agricultural techniques in Brazil: Adoption barriers and potential solutions, Technical paper, Climate Policy Initiative, PUC-Rio, Rio de Janeiro, 2013.

Axelrod, R. (Ed.): Structure of decision: The cognitive maps of political elites, Princeton University Press, Princeton, NJ, USA, 422 pp., 1976.

Bicalho, A. M. S. M. and Hoefle, S. W.: Conservation units, environmental services and frontier peasants in the Central Amazon: Multi-functionality, juxtaposition or conflict?, in: Climate change, culture, and economics: Anthropological investigations (Research in economic anthropology, Volume 35), edited by: Wood, D. C., Emerald Group Publishing Limited, 65-105, https://doi.org/10.1108/S0190-128120150000035004, 2015.

Brondizio, E. S. and Moran, E. F.: Human dimension of climate change: The vulnerability of small farmers in the Amazon, Philos T. Roy. Soc. B, 363, 1803-1809, https://doi.org/10.1098/rstb.2007.0025, 2008.

Carr, D.: Population and deforestation: Why rural migration matters, Prog. Hum. Geog., 33, 355-378, https://doi.org/10.1177/0309132508096031, 2009.

Caviglia-Harris, J., Sills, E., Bell, A., Harris, D., Mullan, K., and Roberts, D.: Busting the boom- Bust pattern of development in the Brazilian Amazon, World Dev., 79, 82-96, https://doi.org/10.1016/j.worlddev.2015.10.040, 2016.

Celentano, D., Sills, E., Sales, M., and Veríssimo, A.: Welfare outcomes and the advance of the deforestation frontier in the Brazilian Amazon, World Dev., 40, 850-864, https://doi.org/10.1016/j.worlddev.2011.09.002, 2012. 
Chomitz, K. M.: At loggerheads? Agricultural expansion, poverty reduction, and environment in the tropical forests, World Bank, Washington, D.C., USA, 2007.

Devisscher, T., Boyd, E., and Malhi, Y.: Anticipating future risk in social-ecological systems using fuzzy cognitive mapping: The case of wildfire in the Chiquitania, Bolivia, Ecol. Soc., 21, 18, https://doi.org/10.5751/ES-08599-210418, 2016.

Dubois, J.: Preliminary forest management guidelines for the National Forest of Tapajós, Belém, FAO/PRODEPEF Northern Region, Belém, Pará, 41 pp., 1976.

Fairweather, J.: Farmer models of socio-ecologic systems: Application of causal mapping across multiple locations, Ecol. Model., 221, 555-562, https://doi.org/10.1016/j.ecolmodel.2009.10.026, 2010.

Fearnside, P. M.: Brazil's Cuiabá-Santarém (BR-163) Highway: The environmental cost of paving a soybean corridor through the Amazon, J. Environ. Manage., 39, 601-614, https://doi.org/10.1007/s00267-006-0149-2, 2007.

Fearnside, P. M.: Amazon dams and waterways: Brazil's Tapajós Basin plans, Ambio, 44, 426-439, https://doi.org/10.1007/s13280-015-0642-z, 2015.

Ferraro, P. J. and Pattanayak, S. K.: Money for nothing? A call for empirical evaluation of biodiversity conservation investments, PLoS Biol., 4, 482-488, https://doi.org/10.1371/journal.pbio.0040105, 2006.

Foley, J. A., Asner, G. P., Costa, M. H., Coe, M. T., DeFries, R., Gibbs, H. K., Howard, E. A., Olson, S., Patz, J., Ramankutty, N., and Snyder, P.: Amazonia revealed: Forest degradation and loss of ecosystem good and services in the Amazon Basin, Front. Ecol. Environ., 5, 25-32, https://doi.org/10.1890/15409295(2007)5[25:ARFDAL]2.0.CO;2, 2007.

Folhes, R. T., Aguiar, A. P. D., de Stoll, E., Dalla-Nora, E. L., Araújo, R., Coelho, A., and do Canto, O.: Multiscale participatory scenario methods and territorial planning in the Brazilian Amazon, Futures, 73, 86-99, https://doi.org/10.1016/j.futures.2015.08.005, 2015.

Freeman, L. C.: A Set of Measures of Centrality Based on Betweenness, Sociometry, 40, 35-41, https://doi.org/10.2307/3033543, 1977.

Freeman, L. C.: Centrality in social networks conceptual clarification, Soc. Networks, 1, 215-239, https://doi.org/10.1016/03788733(78)90021-7, 1978.

Garcia, A., Vilela, V. M. d. F. N., Rizzo, R., West, P. C., Gerber, J. S., Engstrom, P. M., and Ballester, M. V.: Assessing land use/cover dynamics and exploring drivers in the Amazon's arc of deforestation through a hierarchical, multi-scale and multi-temporal classification approach, Remote Sensing Applications: Society and Environment, 15, 100233, https://doi.org/10.1016/j.rsase.2019.05.002, 2019.

Gibbs, H. K., Rausch, L., Munger, J., Schelly, I., Morton, D. C., Noojipady, P., Soares-Filho, B., Barreto, P., Micol, L., and Walker, N. F.: Brazil's Soy Moratorium. Supply-chain governance is needed to avoid deforestation, Science, 347, 377-378, https://doi.org/10.1126/science.aaa0181, 2015.

Global Forest Watch: https://www.globalforestwatch.org/map, last access: 17 September 2019

Godfray, H. C. J., Pretty, J., Thomas, S. M., Warham, E. J., and Beddington, J. R.: Linking policy on climate and food, Science, 331, 1013-1014, https://doi.org/10.1126/science.1202899, 2011.
Gray, S. A., Gray, S., de Kok, J. L., Helfgott, A. E. R., O’Dwyer, B., Jordan, R., and Nyaki, A.: Using fuzzy cognitive mapping as a participatory approach to analyze change, preferred states, and perceived resilience of social-ecological systems, Ecol. Soc., 20, 11, https://doi.org/10.5751/ES-07396-200211, 2015.

Guedes, G. R., VanWey, L. K., Hull, J. R., Antigo, M., and Barbieri, A. F.: Poverty dynamics, ecological endowments, and land use among smallholders in the Brazilian Amazon, Soc. Sci. Res., 43, 74-91, https://doi.org/10.1016/j.ssresearch.2013.09.002, 2014.

Guimberteau, M., Ciais, P., Ducharne, A., Boisier, J. P., Dutra Aguiar, A. P., Biemans, H., De Deurwaerder, H., Galbraith, D., Kruijt, B., Langerwisch, F., Poveda, G., Rammig, A., Rodriguez, D. A., Tejada, G., Thonicke, K., Von Randow, C., Von Randow, R. C. S., Zhang, K., and Verbeeck, H.: Impacts of future deforestation and climate change on the hydrology of the Amazon Basin: a multi-model analysis with a new set of landcover change scenarios, Hydrol. Earth Syst. Sci., 21, 1455-1475, https://doi.org/10.5194/hess-21-1455-2017, 2017.

Haddad, N. M., Brudvig, L. A., Clobert, J., Davies, K. F., Gonzalez, A., Holt, R. D., Lovejoy, T. E., Sexton, J. O., Austin, M. P., Collins, C. D., Cook, W. M., Damschen, E. I., Ewers, R. M., Foster, B. L., Jenkins, C. N., King, A. J., Laurence, W. F., Levey, D. J., Margules, C. R., Melbourne, B. A., Nicholls, A. O., Orrock, J. L. Song, D.-X., and Townshend, J. R.: Habitat fragmentation and its lasting impact on Earth's ecosystems, Sci. Adv., 1, 1-9, https://doi.org/10.1126/sciadv.1500052, 2015.

Harris, N. L., Brown, S., Hagen, S. C., Saatchi, S. S., Petrova, S., Salas, W., Hansen, M. C., Potapov, P. V., and Lotsch, A.: Baseline map of carbon emissions from deforestation in tropical regions, Science, 336, 1573-1576, https://doi.org/10.1126/science.1217962, 2012.

Hoefle, S. W.: Multi-functionality, juxtaposition and conflict in the Central Amazon: Will tourism contribute to rural livelihoods and save the rainforest?, J. Rural Stud., 44, 24-36, https://doi.org/10.1016/j.jrurstud.2015.12.009, 2016.

Høiby, M. and Zenteno-Hopp, J.: Bolivia: Emerging and traditional elites and the governance of the soy sector, in: Environmental politics in Latin America: Elite dynamics, the left tide and sustainable development, edited by: Bull, B. and Aguilar Støen, M C., Routledge, London, UK, 51-70, 2015.

Hosonuma, N., Herold, M., De Sy, V., De Fries, R. S., Brockhaus, M., Verchot, L., Angelsen, A., and Romijn, E.: An assessment of deforestation and forest degradation drivers in developing countries, Environ. Res. Lett., 7, 1-12, https://doi.org/10.1088/17489326/7/4/044009, 2012.

IBAMA (Instituto Brasileiro do Meio Ambiente e dos Recursos Naturais Renováveis): Plano de manejo Floresta Nacional do Tapajós, 1, Informações Gerais, Brasilia, Brazil, 580 pp, 2004.

INE (Instituto Nacional de Estadistica de Bolivia): Ficha resumen Censo Nacional Agropecuario 2013, available at: https://www.ine.gob.bo/index.php/prensa/publicaciones/ 118-publicaciones/estadisticas-por-actividad-economica/ 158-censo-agropecuario-2013-bolivia (last access: 31 July 2019), 2015.

Ioris, A. A. R.: The paradox of poverty in rich ecosystems: Impoverishment and development in the Amazon of Brazil and Bolivia, Geogr. J., 182, 178-189, https://doi.org/10.1111/geoj.12124, 2016. 
Killeen, T. J., Guerra, A., Calzada, M., Correa, L., Calderon, V., Soria, L., Quezada, B., and Steininger, M. K.: Total historical land-use change in eastern Bolivia: Who, where, when, and how much?, Ecol. Soc., 13, 36, https://doi.org/10.5751/ES-02453130136, 2008.

Kok, K.: The potential of Fuzzy Cognitive Maps for semi-quantitative scenario development, with an example from Brazil, Global Environ. Chang., 19, 122-133, https://doi.org/10.1016/j.gloenvcha.2008.08.003, 2009.

Kok, K. and van Vliet, M.: Using a participatory scenario development toolbox: added values and impact on quality of scenarios, J. Water Clim. Change, 2, 87-105, https://doi.org/10.2166/wcc.2011.032, 2011.

Kosko, B.: Fuzzy cognitive maps, Int. J. Man. Mach. Stud., 24, 6575, https://doi.org/10.1016/S0020-7373(86)80040-2, 1986.

Kosko, K.: Fuzzy systems as universal approximators, IEEE T. Comput., 43, 1329-1333, 1994.

Lapola, D. M., Martinelli, L. A., Peres, C. A., Ometto, J. P. H. B., Ferreira, M. E., Nobre, C. A., Aguiar, A. P. D., Bustamante, M. M. C., Cardoso, M. F., Costa, A. J., Leite, C. C., Sampaio, G., Strassburg, B. N., and Vieira, I. C. G: Pervasive transition of the Brazilian land-use system, Nat. Clim. Change, 4, 27-35, https://doi.org/10.1038/nclimate2056, 2014.

Lenton, T. M.: Early warning of climate tipping points, Nat. Clim. Change, 1, 201-209, https://doi.org/10.1038/nclimate1143, 2011.

Le Tourneau, F.-M., Marchand, G., Greissing, A., Nasuti, S., Droulers, M., Bursztyn, M., Léna, P., and Dubreuil, V.: The DURAMAZ indicator system: A cross-disciplinary comparative tool for assessing ecological and social changes in the Amazon, Philos. T. Roy. Soc. B, 368, 20120475, https://doi.org/10.1098/rstb.2012.0475, 2013.

Malhi, Y., Roberts, J. T., Betts, R. A., Killeen, T. J., Li, W. H., and Nobre, C. A.: Climate change, deforestation, and the fate of the Amazon, Science, 319, 169-172, https://doi.org/10.1126/science.1146961, 2008.

Manners, R. and Varela-Ortega, C.: The role of decisionmaking in ecosystem service trade-offs in lowland Bolivia's Amazonian agricultural systems, Ecol. Econ., 153, 31-42, https://doi.org/10.1016/j.ecolecon.2018.06.021, 2018.

McNeil, D., Verburg, R., and Bursztyn, M.: Institutional context for sustainable development, in: Land use policies for sustainable development. Exploring integrated assessment approaches, edited by: McNeil, D., Nesheim, I., and Brouwer, F., Edward Elgar, Cheltenham, UK, Northampton, MA, USA, 24-44, 2012.

Müller, R., Pacheco, P., and Montero, J. C.: The context of deforestation and forest degradation in Bolivia: Drivers, agents and institutions, Occasional Paper, 108, CIFOR, Bogor, Indonesia, https://doi.org/10.17528/cifor/004600, 2014.

Nepstad, D., McGrath, D., Stickler, C., Alencar, A., Azevado, A., Swette, B., Bezerra, T., DiGiano, M., Shimada, J., Serioa da Motta, R., Armijo, E., Castello, L., Brando, P., Hansen, M. C., McGrath-Horn, M., Carvalho, O., and Hess, L.: Slowing Amazon deforestation through public policy and interventions in beef and soy supply chains, Science, 344, 1118-1123, https://doi.org/10.1126/science.1248525, 2014.

Newton, P., Argawal, A., and Wollenberg, L.: Enhancing the sustainability of commodity supply chains in tropical forest and agricultural landscapes, Global Environ. Chang., 23, 1761-1772, https://doi.org/10.1016/j.gloenvcha.2013.08.004, 2013.

Nobre, C. A., Sampaio, G., Borma, L. S., Castilla-Rubio, J. C., Silva, J. S., and Cardoso, M.: Land-use and climate change risks in the Amazon and the need of a novel sustainable development paradigm, P. Natl. Acad. Sci. USA, 113, 10759-10768, https://doi.org/10.1073/pnas.1605516113, 2016.

Olazabal, M. and Pascual, U.: Use of fuzzy cognitive maps to study urban resilience and transformation, Environmental Innovation and Societal Transitions, 18, 18-40, https://doi.org/10.1016/j.eist.2015.06.006, 2016.

Oliviera, L. J. C., Costa, M. H., Soares-Filho, B. S., and Coe, M. T.: Large-scale expansion of agriculture in Amazonia may be a no-win scenario, Environ. Res. Lett., 8, 024021, https://doi.org/10.1088/1748-9326/8/2/024021, 2013.

Özesmi, U. and Özesmi, S. L.: Ecological models based on people's knowledge: A multi-step fuzzy cognitive mapping approach, Ecol. Model., 176, 43-64, https://doi.org/10.1016/j.ecolmodel.2003.10.027, 2004.

Pacheco, P.: Agricultural expansion and deforestation in lowland Bolivia: The import substitution versus the structural adjustment model, Land Use Policy, 23, 206-225, 2006.

Page, L., Brin, S., Motwani, R., and Winograd, T.: The PageRank citation ranking: Bringing order to the Web. Technical Report SIDL-WP-1999-0120, Stanford Digital Library, Stanford, USA, 1999.

Papageorgiou, E. I., Aggelopoulou, K. D., Gemtos, T. A., and Nanos, G. D.: Yield prediction in apples using Fuzzy Cognitive Map learning approach, Comput. Electron. Agr., 91, 19-29, https://doi.org/10.1016/j.compag.2012.11.008, 2013.

Pinho, P., Patenaude, G., Ometto, J. P., Meir, P., Toledo, P. M., Coelho, A., and Young, C. E. F.: Ecosystem protection and poverty alleviation in the tropics: Perspective from a historical evolution of policy-making in the Brazilian Amazon, Ecosyst. Serv., 8, 97-109, https://doi.org/10.1016/j.ecoser.2014.03.002, 2014.

Reardon, T. and Vosti, S. A.: Links between rural poverty and the environment in developing countries: Asset categories and investment poverty, World Dev., 23, 1495-1506, https://doi.org/10.1016/0305-750X(95)00061-G, 1995.

Reckien, D.: Weather extremes and street life in IndiaImplications of Fuzzy Cognitive Mapping as a new tool for semi-quantitative impact assessment and ranking of adaptation measures, Global Environ. Chang., 26, 1-13, https://doi.org/10.1016/j.gloenvcha.2014.03.005, 2014.

Rodrigues, A. S. L., Ewers, R. M., Parry, L., Souza Jr., C., Veríssimo, A., and Balmford, A.: Boom-and-bust development patterns across the Amazon deforestation frontier, Science, 324, 1435-1437, https://doi.org/10.1126/science.1174002, 2009.

Rodrigues-Filho, S., Verburg, R., Bursztyn, M., Lindoso, D., Debortoli, N., and Vilhena, A. M. G.: Election-driven weakening of deforestation control in the Brazilian Amazon, Land Use Policy, 43, 111-118, https://doi.org/10.1016/j.landusepol.2014.11.002, 2015.

Salahodjaev, R.: Intelligence and deforestation: International data, Forest Policy Econ., 63, 20-27, https://doi.org/10.1016/j.forpol.2015.12.003, 2016.

Simmons, S. S., Walker, R. T., Arima, E. Y., Aldrich, S. P., and Caldas, M. M.: The Amazon land war in the South of Pará, Ann. 
Assoc. Am. Geogr., 97, 567-592, https://doi.org/10.1111/j.14678306.2007.00564.x, 2007.

Spracklen, D. V. and Garcia-Carreras, L.: The impact of Amazonian deforestation on Amazon basin rainfall, Geophys. Res. Lett., 42, 9546-9522, https://doi.org/10.1002/2015GL066063, 2015.

Stavenhagen, R.: Promotion and protection of all human rights, civil, political, economic, social and cultural rights, including the right to development - Report on the situation of human rights and fundamental freedoms of indigenous people. Mission to Bolivia. United Nations (UN), available at: https://www2.ohchr.org/ english/bodies/hrcouncil/docs/11session/A.HRC.11.11.pdf (last access: 31 July 2019), 2009.

Tejada, G., Dalla-Nora, E., Cordoba, D., Lafortezza, R., Ovando, A., Assis, T., and Aguiar, A. P.: Deforestation scenarios for the Bolivian lowlands, Environ. Res., 144, 49-63, https://doi.org/10.1016/j.envres.2015.10.010, 2016.

Tolman, E. C.: Cognitive maps in rats and men, Psychol. Rev., 55, 189-208, 1948

Tritsch, I. and Arvor, D.: Transition in environmental governance in the Brazilian Amazon: Emergence of a new pattern of socioeconomic development and deforestation, Land Use Policy, 59, 446-455, https://doi.org/10.1016/j.landusepol.2016.09.018, 2016.

Varela-Ortega, C., Blanco, I., Manners, R., Esteve, P., Kok, K., Toledo, M., Martorano, L., Simoes, M., Diniz, F., Lazos, E., and Gerritsen, P.: Methods and results from the first and second of local stakeholder meetings - Part 1, Deliverable D3.1.3, ROBIN Project (No 283093), FP7, DG Research, European Commission, Madrid, Spain, 192 pp., 2013.
Vasslides, J. M. and Jensen, O. P.: Fuzzy cognitive mapping in support of integrated ecosystem assessments: Developing a shared conceptual model among stakeholders, J. Environ. Manage., 15, 348-356, https://doi.org/10.1016/j.jenvman.2015.10.038, 2016.

Verburg, R., Rodrigues-Filho, S., Debortoli, N., Lindoso, D., Nesheim, I., and Bursztyn, M.: Evaluating sustainability options in an agricultural frontier of the Amazon using multi-criteria analysis, Land Use Policy, 37, 27-39, https://doi.org/10.1016/j.landusepol.2012.12.005, 2014.

Weinhold, D., Reis, E. J., and Vale, P. M.: Boom-bust patterns in the Brazilian Amazon, Global Environ. Chang., 35, 391-399, https://doi.org/10.1016/j.gloenvcha.2015.09.013, 2015.

World Bank: The Worldwide Governance Indicators (WGI) project, World Bank, Washington, D.C., USA, available at: http:// info.worldbank.org/governance/wgi/index.aspx\#home (last access: 10 December 2018), 2016.

Zemp, D. C., Schleussner, C.-F., Barbosa, H. M. J., and Rammig, A.: Deforestation effects on Amazon forest resilience, Geophys. Res. Lett., 44, 6182-6190, https://doi.org/10.1002/2017GL072955, 2017. 